\title{
ANALISIS AERODINAMIKA AIRFOIL DENGAN METODA INTERAKSI VISKOS - TAK VISKOS QUASI - SIMULTAN
}

\author{
*Ismoyo Haryanto, Munadi, Achmad Widodo, Toni Prahasto \\ Departemen Teknik Mesin, Fakultas Teknik, Universitas Diponegoro \\ J1. Prof. Soedarto SH, Tembalang, Semarang 50275 Indonesia, Telp/Fax: +62 247460059 \\ *Email: ismoyo_h@undip.ac.id
}

\begin{abstract}
ABSTRAK
Sebuah program komputasi guna analisis aerodinamika airfoil telah dikembangkan. Dalam program komputasi ini metoda panel diaplikasikan dimana model aliran singularitas yang dipilih adalah kombinasi doublet/source. Sedangkan pengaruh viskositas dianalisis dengan menerapkan metoda interaksi viskos - tak viskos. Dengan metoda ini komputasi dilakukan secara itearatif sehingga parameter-parameter aliran yang diperoleh dari analisis tak viskos melalui metoda panel dan yang diperoleh dari analisis lapisan batas memberikan harga yang sama tepat di daerah ujung lapisan batas. Pada penelitian ini pendekatan quasi - simultan dipilih guna pemodelan interaksi viskos - tak viskos. Pendekatan ini dipilih karena konvergensi yang mampu dicapai sekalipun aliran mengalami pemisahan. Program komputasi yang dikembangkan diterapkan untuk analisis aerodinamika airfoil E387, FX 63-137 dan S822. Hasil yang diperoleh menunjukkan bahwa secara umum metoda yang dikembangkan mampu meramalkan koefisien gaya angkat cukup baik dengan tingkat ketelitian sekitar $2 \%$ akan tetapi tidak cukup baik untuk meramalkan koefisien gaya hambat. Dari hasil kaji kasus yang dilakukan juga menunjukkan bahwa metoda yang dikembangkan sudah tidak mampu lagi meramalkan karakteristik aerodinamika airfoil yang cukup tebal.
\end{abstract}

Kata kunci: aerodinamika, airfoil, interaksi viskos - tak viskos, quasi - simultan

\section{Pendahuluan}

Riset dalam pengembangan teknologi airfoil baik untuk kegunaan turbin angin maupun wahana terbang telah banyak dilakukan pada dekade ini. Berbagai profil airfoil telah banyak diperoleh baik dengan metode eksperimental maupun numerik untuk mendapatkan karakteristik aerodinamika airfoil yang sesuai dengan penggunaannya. Akan tetapi karena karakteristik airfoil tergantung banyak hal sehingga dapat dikatakan bahwa tiap airfoil mempunyai penggunaan yang spesifik. Pada prinsipnya bentuk airfoil yang dikehendaki adalah airfoil yang mempunyai angka perbandingan nilai koefisien gaya angkat terhadap koefisien gaya hambat $\left(C_{l} / C_{d}\right)$ tertinggi. Oleh karena itu piranti analisis yang memadai untuk menentukan karakteristik aerodinamika airfoil (dalam bentuk koefisien gaya angkat dan koefisien gaya hambat) secara akurat menjadi sangat penting.

Metoda analisis yang telah secara luas diterapkan dalam analisis aerodinamika pada khususnya dan dinamika fluida pada umumnya adalah Computational Fluid Dynamics (CFD) [1]. Untuk berbagai kasus secara umum analisis menggunakan CFD ini memberikan hasil yang cukup akurat. Meskipun demikian karena dalam analisis menggunakan CFD diperlukan meshing pada bidang fisik yang ditinjau sehingga untuk geometri yang berbeda diperlukan meshing yang berbeda pula maka penggunaan CFD pada tahap perancangan awal kurang menguntungkan karena pada tahap ini masih terjadi iterasi perubahan geometri. Kondisi yang demikian sesungguhnya sudah diatasi dengan dikembangkannya adaptive meshing akan tetapi tetap saja masalah waktu komputasi yang cukup besar menjadikan CFD tidak menguntungkan diterapkan pada tahap perancangan awal. Apalagi penggunaan CFD dalam analisis juga menuntut penyediaan perangkat keras dengan kapasitas yang cukup besar.

Beberapa metode analisis aerodinamika yang tidak melibatkan proses meshing telah dikembangkan pada dekade terakhir ini yang hampir kesemuanya didasarkan pada metoda panel, diantaranya adalah EPPLER (Richard Eppler, et al., 1980) dan XFOIL [2]. Dari beberapa hasil yang diperoleh menunjukkan bahwa kedua piranti lunak tersebut mampu memberikan hasil yang cukup akurat dalam waktu yang relatif singkat. Akan tetapi masalah yang berkaitan dengan kompatibilitas muncul ketika ada keinginan untuk menggabungkan program komputasi tersebut dengan piranti dan metoda analisis dari aspek yang lain. Oleh karena itu piranti analisis aerodinamika airfoil yang mampu meberikan hasil yang akurat dalam waktu yang singkat dan mudah di-interface-kan dengan piranti analisis yang lainnya sangat diperlukan.

Pada penelitian ini akan disusun piranti lunak program komputasi analisis aerodinamika yang mampu memberikan hasil yang akurat dan dalam waktu yang cukup singkat. Program komputasi yang disusun didasarkan pada metoda panel, dimana sebagai model aliran singularnya adalah doublet dan source sebagai modul analisis aerodinamika tak viskosnya. Adapun efek viskos nya akan dianalisis menggunakan prinsip interaksi viskos - tak viskos model quasi simultan yang telah dikembangkan oleh Veldman [3-5]. 


\section{Metodologi}

Prosedur metoda interaksi viskos - tak viskos guna analisis aerodinamika airfoil ini meliputi: (i) analisis aerodinamika tak viskos, (ii) analisis lapisan batas dan (iii) interaksi viskos - tak viskos. Secara umum prosedur tersebut ditunjukkan pada Gambar 1 di bawah.

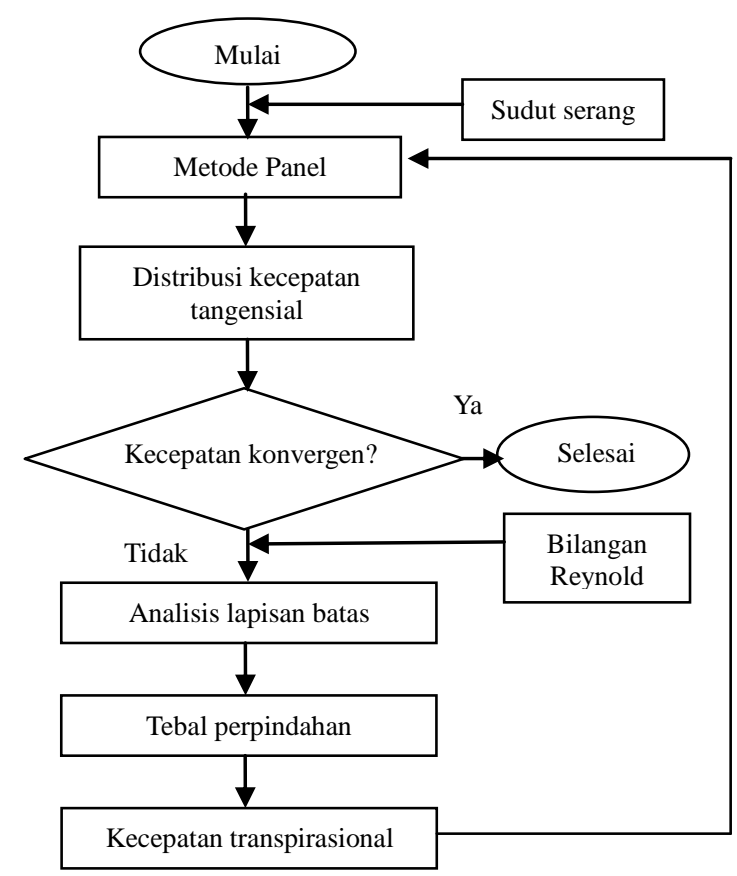

Gambar 1. Diagram alir metoda interaksi viskos - tak viskos

Langkah pertama adalah analisis aerodinamika tak viskos pada sudut serang yang dikaji. Langkah ini dimaksudkan untuk mendapatkan distribusi kecepatan tangensial di sepanjang permukaan airfoil. Informasi mengenai distribusi kecepatan tangensial ini diperlukan sebagai masukan dalam analisis lapisan batas (boundary layers) pada bilangan Reynold tertentu untuk menentukan tebal perpindahan (displacement thickness). Selanjutnya dengan metoda interaksi viskos - tak viskos, baik distribusi kecepatan maupun distribusi ketebalan perpindahan di update sehingga diperoleh solusi yang konvergen. Konvergensi solusi ini ditunjukkan dengan diperolehnya distribusi kecepatan tangensial dan tebal perpindahan tepat di ujung lapisan batas (batas antara daerah viskos dan tak viskos) baik yang diperoleh melalui analisis aerodinamika tak viskos maupun analisis lapisan batas berharga sama. Perlu dicatat bahwa dalam penyelesaian masalah lapisan batas banyak persamaan klosur yang digunakan didasarkan pada data-data empirik yang diperoleh dari eksperimen. Kekurangtepatan dapat saja terjadi karena ketidakkonsistenan dalam pemilihan persamaan klosur yang digunakan. Hal lain yang perlu dicermati adalah analisis pada kondisi aliran memisah dimana di daerah ini beberapa pengaturan (adjustment) adakalanya diperlukan.

\section{Analisis Aerodinamika Tak Viskos}

Pada aliran tak viskos, tak rotasional dan tak termampatkan (incompressible) potensial kecepatan totalnya, $\Phi$, dinyatkan dengan persamaan Laplace berikut:

$$
\nabla^{2} \Phi=0
$$

Berdasarkan persamaan Laplace pada Pers. (1) di atas selanjutnya prediksi karakteristik aerodinamik dari kebanyakan bentuk airfoil dapat ditentukan secara relatif akurat dengan menggunakan metode panel dua dimensi (Katz \& Plotkin; 2001). Dengan metoda ini mula-mula permukaan airfoil dibagi menjadi sejumlah panel seperti ditunjukkan Gambar 3. Selanjutnya pada setiap panel diterapkan model aliran singularitas.

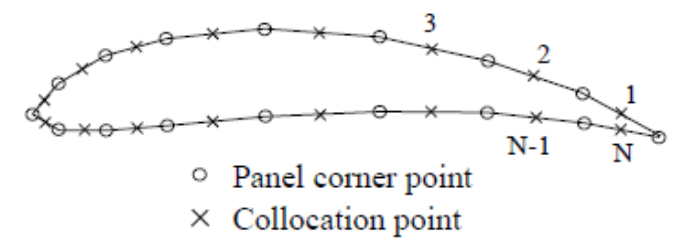

Gambar 3. Pembuatan panel pada airfoil 
Dalam penelitian ini model singularitas yang dipilih adalah kombinasi source dan doublet. Model kombinasi ini dipilih karena mampu memberikan hasil yang cukup akurat sekalipun hanya dengan membagi airfoil dalam sejumlah kecil panel. Gambar 4 memberikan gambaran bahwa hanya dengan menetapkan 10 panel model singularitas kombinasi source dan doublet mampu memberikan hasil distribusi tekanan yang yang tidak berbeda jauh dengan hasil yang diberikan dengan menggunakan pendekatan 90 panel maupun dengan hasil yang diperoleh dari solusi analitik. Oleh karena itu diharapkan bahwa dengan pemilihan singularitas kombinasi source dan doublet dalam penelitian ini dapat mempersingkat waktu komputasi.

Dengan menggunakan model aliran singularitas source dan doublet ini solusi potensial kecepatan totalnya dapat diformulasikan mengikuti identitas Green dengan menjumlahkan distribusi source $\sigma$ dan doublet $\mu$ pada permukaan airfoil $S_{\mathrm{B}}$ dinyatakan dengan Pers. (2) berikut:

$$
\Phi(x, y)=\frac{-1}{4 \pi} \int_{S_{B}}\left[\sigma\left(\frac{1}{r}\right)-\mu \mathbf{n} \cdot \nabla\left(\frac{1}{r}\right)\right] d S+\Phi_{\infty}
$$

Pada Pers. (2) $\mathbf{n}$ menyatakan vektor arah normal $S_{\mathrm{B}}$ sedangkan $\Phi_{\infty}$ menyatakan potensial kecepatan pada aliran bebas dan dinyatakan dengan

$$
\Phi_{\infty}=U_{\infty} x+V_{\infty} y
$$

dimana $U_{\infty}$ dan $V_{\infty}$ masing-masing menyatakan kecepatan aliran bebas arah sumbu $x$ dan sumbu $y$.

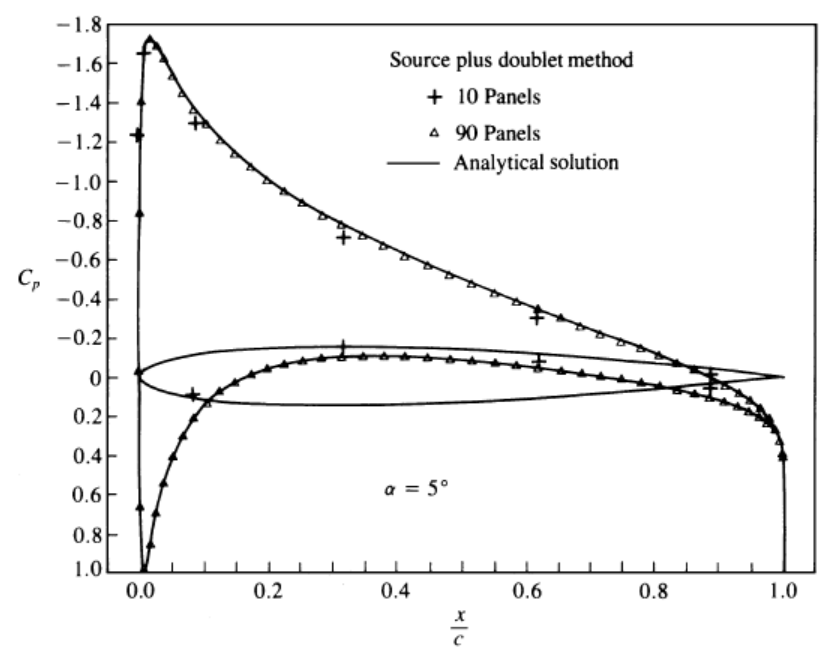

Gambar 4. Distribusi tekanan airfoil simetri dengan 10 dan 90 panel [6].

Pada penerapannya Pers. (2) melibatkan ulakan (wake) selepas airfoil yang dimodelkan sebagai lembaran doublet tipis (thin doublet sheets) sehingga persamaannya menjadi

$\Phi(x, y)=\frac{1}{4 \pi} \int_{b o d y+w a k e} \mu \mathbf{n} \cdot \nabla\left(\frac{1}{r}\right) d S-\frac{1}{4 \pi} \int_{b o d y} \sigma\left(\frac{1}{r}\right) d S+\Phi_{\infty}$

Untuk sejumlah N panel Pers. (4) dapat diformulasikan kembali dalam bentuk

$\sum_{i+1}^{N} B_{i} \sigma_{i}+\sum_{i+1}^{N} C_{i} \mu_{i}=0$

Selanjutnya dengan menerapkan kondisi batas Dirichlet, kekuatan source dapat dinyatakan sebagai

$\sigma=\mathbf{n} \cdot \mathbf{Q}_{\infty}$

Adapun kekuatan doublet di trailing edge harus memenuhi kondisi Kutta yang dinyatakan dengan 
$\left(\mu_{1}-\mu_{N}\right)+\mu_{W}=0$

Pada Pers. (7) di atas $\mu_{W}$ menyatkan kekuatan doublet di daerah wake. Substitusi Pers. (6) ke suku pertama Pers. (5) dan dengan mengingat kondisi Kutta pada Pers. (7) maka diperoleh persamaan aljabar linier simultan yang dapat diselesaikan dengan metoda numerik standar untuk mendapatkan kekuatan doublet $\mu$ di setiap titik kolokasi. Setelah seluruh kekuatan doublet $\mu$ diketahui maka distribusi kecepatan tangesial di setiap titik atur, $U_{e}$, dapat dihitung dengan menggunakan Pers. (8) berikut:

$u_{e}=\frac{\mu_{i}-\mu_{i+1}}{\Delta l_{i}}+Q_{t \infty}$

dimana $Q_{t \infty}$ adalah kecepatan aliran bebas dalam arah tangensial dan $\Delta l_{i}$ adalah jarak antara dua titik kolokasi yang saling berdekatan. Selanjutnya koefisien tekanan pada titik atur ke- $i$ dapat ditentukan dengan menggunakan Pers. (9).

$C_{p i}=1-\frac{u_{e}^{2}}{u_{\infty}^{2}}$

dimana $U_{\infty}$ menyatakan kecepatan aliran bebas.

Dengan dapat ditentukannya distribusi koefisien tekanan di sepanjang permukaan airfoil, $C_{p i}$, maka karakteristik aerodinamika yang dinyatakan dengan koefisien gaya dan momen aerodinamika dapat ditentukan dengan dengan mengintegrasikan koefisien tekanan tersebut di sepanjang permukaan airfoil.

\section{Interaksi Viskos -Tak Viskos}

Solusi yang diperoleh dari metode panel adalah kondisi dimana aliran dianggap tak viskos. Dengan anggapan ini maka kondisi batas yang digunakan hanya seperti yang dinyatakan pada Pers. (6). Akan tetapi untuk kondisi aliran dimana sudut serang cukup tinggi solusi yang diperoleh dengan pendekatan di atas sudah tidak akurat lagi. Untuk memperbaiki hasil yang diperoleh maka pengaruh viskositas harus diperhitungkan.

Salah satu pendekatan yang melibatkan pengaruh viskositas dalam analisis aerodinamika adalah metode interaksi viskos - tak viskos. Metoda ini didasarkan pada kenyataan empiris bahwa efek viskositas hanya terjadi di daerah tipis pada permukaan airfoil yang disebut dengan lapisan batas (boundary layers) (lihat Gambar 5. Pada Gambar 5 garis putus-putus menunjukkan batas antara daerah viskos dan tak viskos. Terdapat dua variabel utama pada masalah lapisan batas, yaitu tebal perpindahan (displacement thikckness) dan tebal momentum (momentum thikness) yang masing-masing diformulasikan sebagai

$$
\begin{aligned}
\delta^{*} & \equiv \int_{0}^{\infty}\left(1-\frac{u_{e}}{u_{\infty}}\right) d y \\
\theta & \equiv \int_{0}^{\delta} \frac{u}{u_{e}}\left(1-\frac{u}{u_{e}}\right) d y
\end{aligned}
$$

Interaksi antara viskos dan tak viskos terjadi tepat pada batas tebal perpindahan yang ditunjukkan oleh garis putus-putus. Pada metoda ini konvergensi terjadi jika pada garis putus-putus parameter aliran yang meliputi tebal perpindahan, $\delta^{*}$, dan kecepatan tangensial, $u_{e}$, baik yang diperoleh melalui analisis aerodinamika tak viskos maupun analisis lapisan batas memberikan harga yang sama.

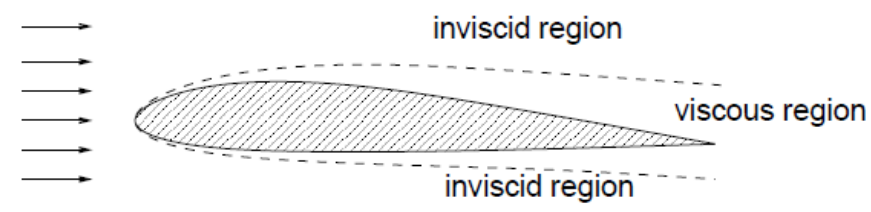

Gambar 5. Pembagian daerah viskos dan tak viskos

Pada semua metoda interaksi viskos - tak viskos yang telah dikembangkan selalu menerapkan analogi Lighthill dimana kecepatan transpirasionalnya dinyatakan dengan [7].

$u_{t}=\frac{\partial\left(u_{e} \delta^{*}\right)}{\partial x}$ 
Sehingga kekuatan source pada Pers. (6) menjadi

$$
\sigma=\mathbf{n} \cdot \mathbf{Q}_{\infty}-\frac{\partial\left(u_{e} \delta^{*}\right)}{\partial x}
$$

Dalam penelitian metoda interaksi viskos - tak viskos adalah metoda quasi - simultan. Pendekatan ini pertamakali dikembangkan oleh Veldman [3-5]. Metoda ini dipilih karena mampu menggabungkan keunggulan yang diperoleh dengan metoda simultan penuh (fully simultaneous) dan metoda langsung (direct method) [8]. Dengan metoda simultan penuh konvergensi tetap dapat dicapai sekalipun pada kondisi aliran memisah. Akan tetapi metoda simultan penuh ini melibatkan matriks dengan ukuran yang relatif besar sehingga membutuhkan waktu komputasi yang cukup lama. Sedangkan metoda langsung sekalipun cukup sederhana (hanya bekerja dengan matriks dengan ukuran relatif kecil) dan memberikan solusi yang cukup akurat di daerah aliran menempel akan tetapi pada sudut serang yang cukup tinggi dimana pemisahan aliran terjadi metoda ini tak mampu lagi mencapai konvergensi. Dengan metoda quasi simultan matriks yang terlibat relatif kecil akan tetapi tetap mampu mencapai konvergensi sekalipun aliran dalam kondisi memisah. Akan tetapi dengan metoda ini dibutuhkan model interaksi. Secara skematis metoda quasi - simultan ini ditunjukkan pada Gambar 6.

Model interaksi yang diterapkan pada pendekatan quasi - simultan dipilih sedemikian hingga mampu merepresentasikan model aliran tak viskos dan pada kondisi konvergen tidak mempunyai pengaruh apapun. Sebagai model interaksi Veldman menerapkan persamaan klasik aliran tak viskos untuk airfoil tipis yang dikombinasi dengan analogi tarnspirasi Lighthill dan dituliskan dalam bentuk [5].

$$
u_{e}=u_{e_{0}}+\frac{1}{\pi} \int_{L E}^{T E} \frac{d\left(u_{e_{0}} \delta^{*}\right)}{d x} \frac{d \varsigma}{x-\varsigma}
$$

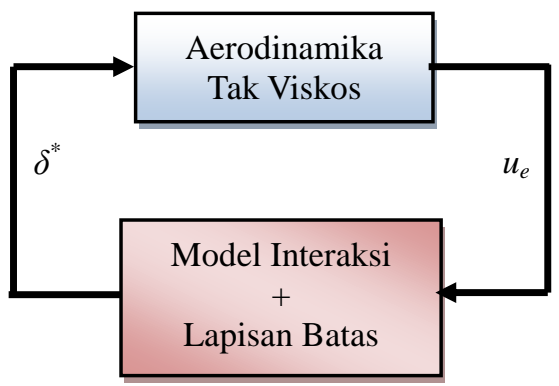

Gambar 6. Skema metoda interaksi viskos - tak viskos dengan pendekatan quasi - simultan

Pada Pers. (13) $u_{e_{0}}$ menyatakan kecepatan yang diperoleh dari solusi komputasi tak viskos tanpa transpirasi dan $u_{e}$ menyatakan kecepatan dengan pengaruh adanya tebal perpindahan $\delta^{*}$. Selanjutnya dengan diskritisasi integral pada Pers. (13) dan dengan ukuran grid $\Delta x$ diperoleh persamaan hukum interaksi untuk 2-D sebagai

$$
u_{e}-c \delta^{*}=E ; \quad E=u_{e x t}-c \delta_{e x t}^{*} ; \quad c=\frac{4 u_{\infty}}{\pi \Delta x}>0
$$

Harga-harga $u_{\text {ext }}$ dan $\delta_{\text {ext }}^{*}$ diperoleh dari kalkulasi tak viskos sebelumnya. Selanjutnya persamaan lapisan batas didasarkan pada persamaan von Karman yang untuk kondisi stedi diformulasikan sebagai

$$
\frac{1}{u_{e}^{2}} \frac{\partial u_{e}^{2} \theta}{\partial x}+\frac{\delta^{*}}{u_{e}} \frac{\partial u_{e}}{\partial x}=\frac{C_{f}}{2}
$$

Pada Pers. (15) $C_{f}$ menyatakan koefisien gesekan. Untuk aliran laminar energi mekanisnya dinyatakan dengan

$$
\frac{1}{u_{e}^{3}} \frac{\partial u_{e}^{3} \delta^{k}}{\partial x}=C_{D}
$$

Dimana $C_{D}$ menyatakan koefisien disipasi dan $\delta^{k}$ diformulasikan pada Apendiks. Sedangkan untuk aliran turbulen 
persamaan Head entrainmennya adalah

$\frac{1}{u_{e}} \frac{\partial}{\partial x}\left(\frac{H_{1} \delta^{*} u_{u}}{H}\right)=C_{E}$

Dimana $C_{E}$ adalah koefisien entraintmen, $H$ menyatakan fungsi bentuk (shape function, $H \equiv \delta^{*} / \theta$ ) dan $H_{1}$ diformulasikan pada Apendiks.

Substitusi Pers. (14) ke Pers. (16) dan (17) diperoleh

$\frac{\partial}{\partial x}\left(\frac{\delta^{*}}{H}\right)+\frac{c \delta^{*}}{u_{e}}\left(1+\frac{2}{H}\right) \frac{\partial \delta^{*}}{\partial x}=\frac{C_{f}}{2}+\frac{\delta^{*}}{u_{e}}\left(1+\frac{2}{H}\right) \frac{\partial E}{\partial x}$

$\frac{\partial \delta^{k}}{\partial x}+3 c \delta^{k} \frac{\partial \delta^{*}}{\partial x}=C_{D}-\frac{3 \delta^{k}}{u_{e}} \frac{\partial E}{\partial x}$

Sedangkan substitusi Pers. (14) ke Pers. (15) dan (17) diperoleh

$-\frac{\delta^{*}}{H^{2}} \frac{\partial H}{\partial x}+\left[\frac{1}{H}+\frac{c \delta^{*}}{u_{e}}\left(1+\frac{2}{H}\right)\right] \frac{\partial \delta^{*}}{\partial x}=\frac{C_{f}}{2}-\frac{\delta^{*}}{u_{e}}\left(1+\frac{2}{H}\right) \frac{\partial E}{\partial x}$
$\frac{H_{1}}{H}\left(1+\frac{c \delta^{*}}{u_{e}}\right) \frac{\partial \delta^{*}}{\partial x}+\frac{\delta^{*}}{H^{*}}\left(\frac{d H_{1}}{d H}-\frac{H_{1}}{H}\right) \frac{\partial H}{\partial x}=C_{E}+\frac{\delta^{*}}{u_{e}} \frac{H_{1}}{H} \frac{\partial E}{\partial x}$

Dengan menuliskan variabel yang belum diketahui sebagai $\phi=\left\{\delta^{*}, H\right\}^{T}$ maka baik Per. (18) maupun (19) dapat dituliskan dalam bentuk

$$
Q\left\{\frac{\partial \phi}{\partial x}\right\}=R
$$

dimana untuk aliran laminar

$$
\begin{aligned}
& Q_{\text {lam }}=\left[\begin{array}{cc}
\frac{1}{H}+\frac{c \delta^{*}}{u_{e}}\left(1+\frac{2}{H}\right) & -\frac{\delta^{*}}{H^{2}} \\
\frac{3 H^{*} c \delta^{*}}{H u_{e}}+\frac{H^{*}}{H} & \frac{\delta^{*}}{H}\left(\frac{d H^{*}}{d H}-\frac{H^{*}}{H}\right)
\end{array}\right] \\
& R_{\text {lam }}=\left\{\begin{array}{c}
\frac{C_{f}}{2}-\frac{\delta^{*}}{u_{e}}\left(1+\frac{2}{H}\right) \frac{\partial E}{\partial x} \\
C_{D}-\frac{3 \delta^{k}}{u_{e}} \frac{\partial E}{\partial x}
\end{array}\right\}
\end{aligned}
$$

dan untuk aliran turbulen

$$
\begin{aligned}
& Q_{\text {turb }}=\left[\begin{array}{cc}
\frac{1}{H}+\frac{c \delta^{*}}{u_{e}}\left(1+\frac{2}{H}\right) & -\frac{\delta^{*}}{H^{2}} \\
\frac{H_{1}}{H}\left(1+\frac{c \delta^{*}}{u_{e}}\right) & \frac{\delta^{*}}{H^{*}}\left(\frac{d H_{1}}{d H}-\frac{H_{1}}{H}\right)
\end{array}\right] \\
& R_{\text {turb }}=\left\{\begin{array}{c}
\frac{C_{f}}{2}-\frac{\delta^{*}}{u_{e}}\left(1+\frac{2}{H}\right) \frac{\partial E}{\partial x} \\
C_{E}-\frac{H_{1} \delta^{*}}{u_{e} H} \frac{\partial E}{\partial x}
\end{array}\right\}
\end{aligned}
$$


Pers. (20) diselesaikan secara numerik dengan terlebih dahulu diterapkan skema diskritisasi standar. Selanjutnya sebagai harga tebakan awal untuk $\delta^{*}$ dan $H$ digunakan pendekatan yang diperoleh menggunakan metoda Thwaites. Penyelesaian dilakukan secara iteratif. Untuk setiap iterasi ke- $n$ kecepatan diupdate dengan menggunakan formulasi

$u_{e}^{(n)}=u_{e}^{(n-1)}-c\left(\delta^{*(n-1)}-\delta^{*(n)}\right)$

Iterasi terus dilakukan hingga diperoleh harga kecepatan konvergen. Harga $\delta^{*}$ yang diperoleh pada kondisi $u_{e}$ konvergen ini selanjutnya disubstitusikan pada Pers. (12) untuk menentukan distribusi $u_{e}$ yang baru menggunakan metoda panel. Prosedur tersebut terus diulangai hingga distribusi kecepatan yang baru konvergen.

\section{Hasil dan Diskusi}

Program komputasi yang telah dikembangkan selanjutnya diterapkan pada airfoil E387, FX 63-137 dan S822. Ketiga airfoil tersebut biasanya diterapkan untuk kincir angin ukuran kecil. Adapun alasan pemilihan airfoil-airfoil tersebut adalah karena ketiganya dipandang cukup mewakili variasi ketebalan dan camber. Hasil-hasil analisis ketiga airfoil tersebut disajikan pada Gambar 7 hingga Gambar 12. Pada gambar tersebut juga diberikan profil geometri airfoil yang dimaksud serta harga koesisien gaya angkat $C_{l}$ dan koefisien gaya hambat $C_{d}$ yang diperoleh dari pengujian terowongan angin yang dilakukan oleh Selig dkk [9].

Gambar 7 menunjukkan distribusi kecepatan tangensial airfoil E387 untuk beberapa sudut serang pada kondisi tak viskos dan juga profil geometri airfoil serta variasi $C_{l}$ terhadap $\alpha$. Adapun $C_{l}$ dan $C_{d}$ airfoil E387 untuk $R e=$ 300000 diberikan pada Gambar 8a dan 8b. Dari Gambar 8a tampak bahwa harga $C_{l}$ untuk airfoil E387 yang diperoleh dari penelitian ini mempunyai akurasi yang cukup tinggi yaitu sekitar $2 \%$ jika dibandingkan dengan hasil pengujian terowongan angin. Pada Gambar 8a juga tampak bahwa baik dari hasil analisis pada penelitian ini maupun dari hasil uji terowongan angin memberikan $\alpha$ stall yang sama yaitu sekitar $9^{\circ}$ sedangkan $C_{l}$ maksimum yang diperoleh dari analisis pada penelitian ini memberikan harga yang lebih tinggi dibanding yang diperoleh dari eksperimen. Sekalipun demikian perbedaan antar keduanya tidak cukup signifikan yaitu hanya sekitar $4 \%$.

Berbeda dari koefisien gaya angkat, koefisien gaya hambat $C_{d}$ yang diperoleh dari analisis pada penelitian ini memberikan perbedaan harga yang cukup besar dibanding dengan $C_{d}$ yang diperoleh dari uji terowongan angin, yaitu sekitar 22\%. Hal ini dapat dilihat pada Gambar 8 b.

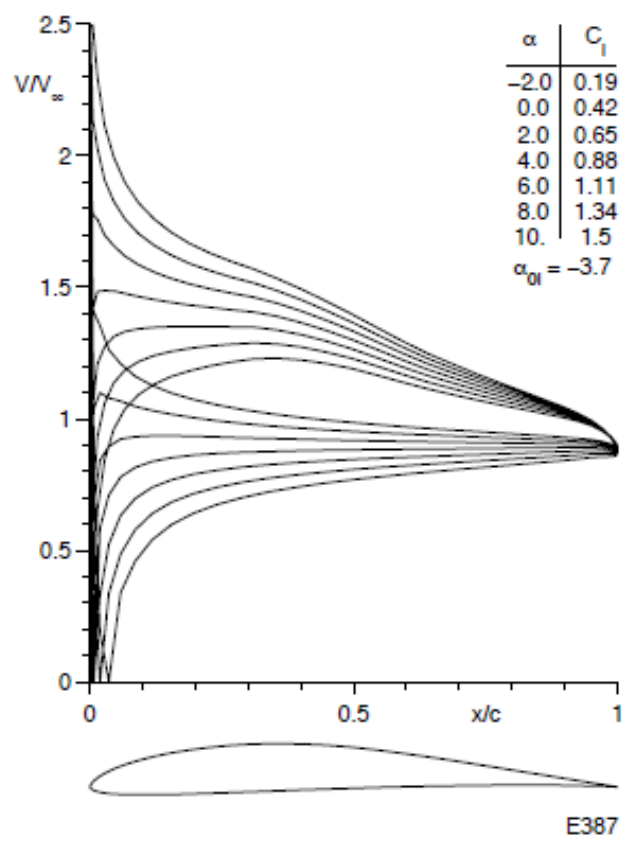

Gambar 7. Distribusi kecepatan tangensial dan profil airfoil E387

Sedangkan hasil analisis kondisi tak viskos untuk airfoil FX 63-137 yang dinyatakan dengan distribusi kecepatan tangensial di sepanjang permukaan airfoil diberikan oleh Gambar 9. Pada gambar tersebut juga ditampilkan $C_{l}$ untuk berbagai $\alpha$ pada kondisi tak viskos. Adapun Gambar 10 menyajikan $C_{l}$ dan $C_{d}$ untuk kondisi viskos dibandingkan dengan hasil eksperimen untuk $R e=200000$. Tampak dari Gambar 10a bahwa hasil analisis pada penelitian ini memberikan $C_{l}$ yang cukup teliti dengan angka ketelitian sekitar $2 \%$. Akan tetapi ketelitian $C_{d}$ yang diperoleh tidak cukup baik, yaitu sekitar $11 \%$. Dari Gambar 10a tampak pula bahwa $C_{l}$ maksimum yang diperoleh dari analisis dengan 
metode yang dikembangkan adalah sekitar 1.83 sedangkan dari pengujian terowongan angin diperoleh 1.72. Meskipun demikian baik dari analisis maupun dari pegujian diperoleh $\alpha$ stall yang kurang lebih sama yaitu sekitar $11^{\circ}$.

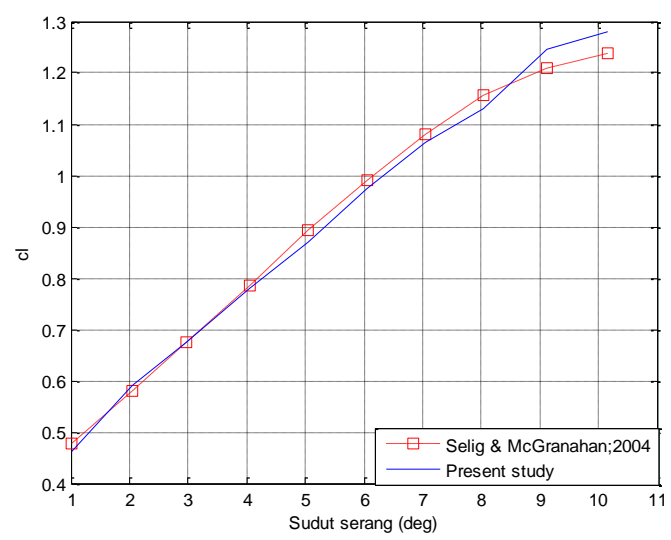

(a)

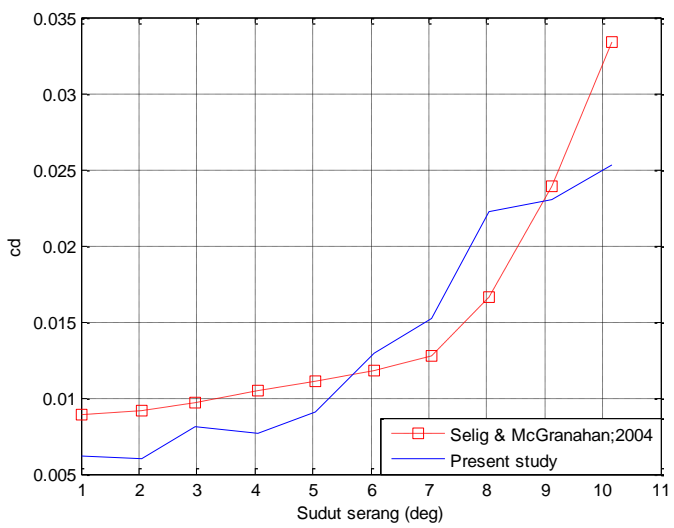

(b)

Gambar 8. (a) Koefisien gaya angkat dan (b) koefisien gaya hambat airfoil E387 untuk $\operatorname{Re}=300000$

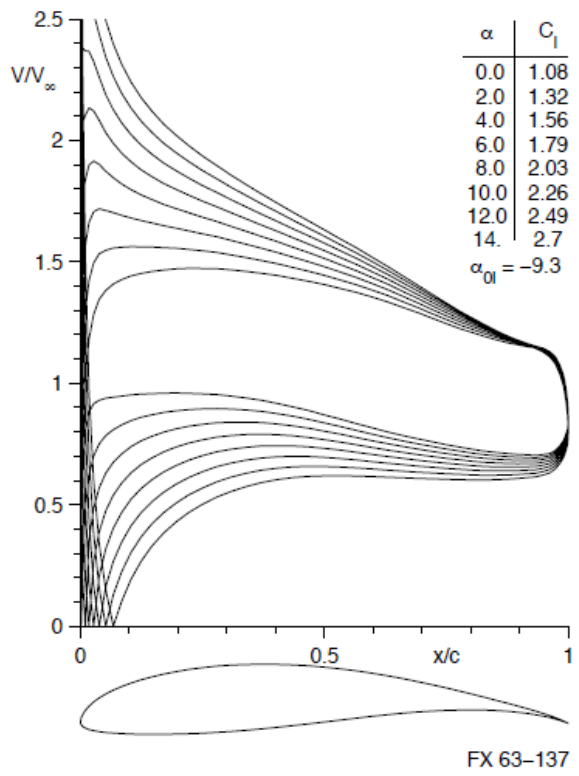

Gambar 9. Distribusi kecepatan tangensial dan profil airfoil FX 63-137 


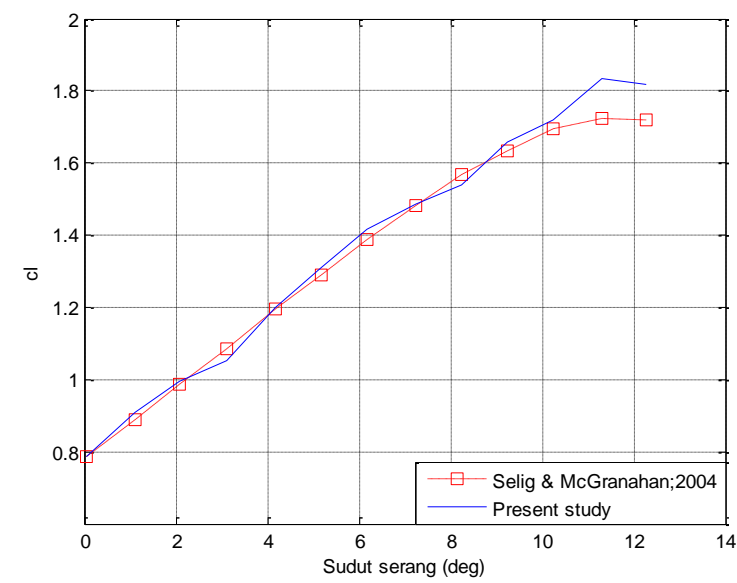

(a)

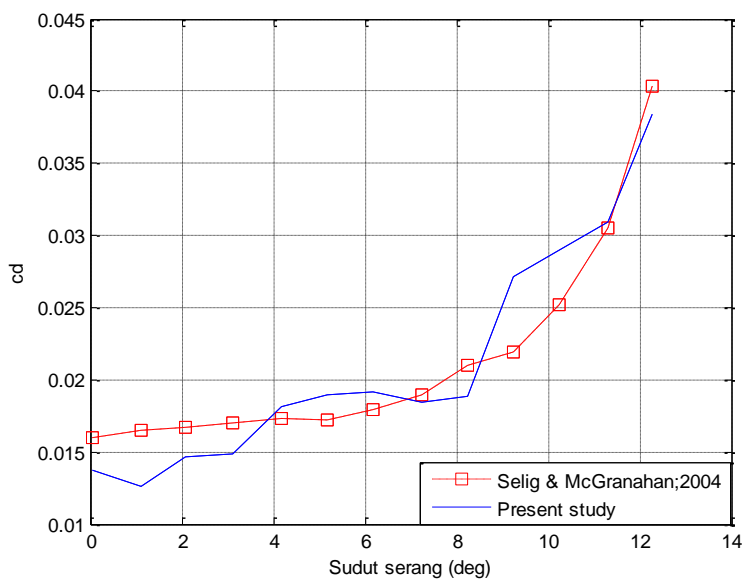

(b)

Gambar 10. Koefisien gaya angkat dan (b) koefisien gaya hambat airfoil FX 63-137 untuk $R e=200000$

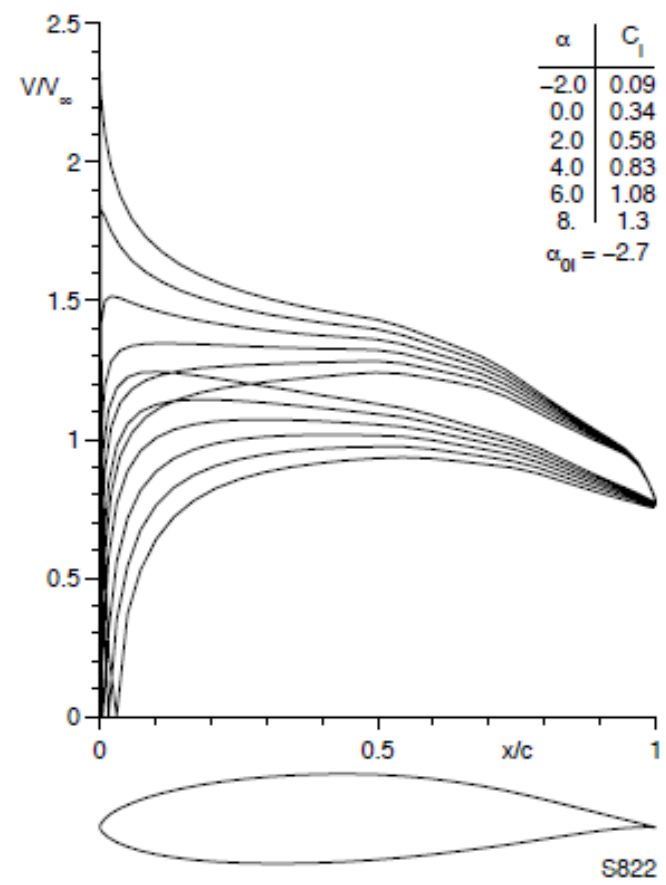

Gambar 11. Distribusi kecepatan tangensial dan profil airfoil S822 


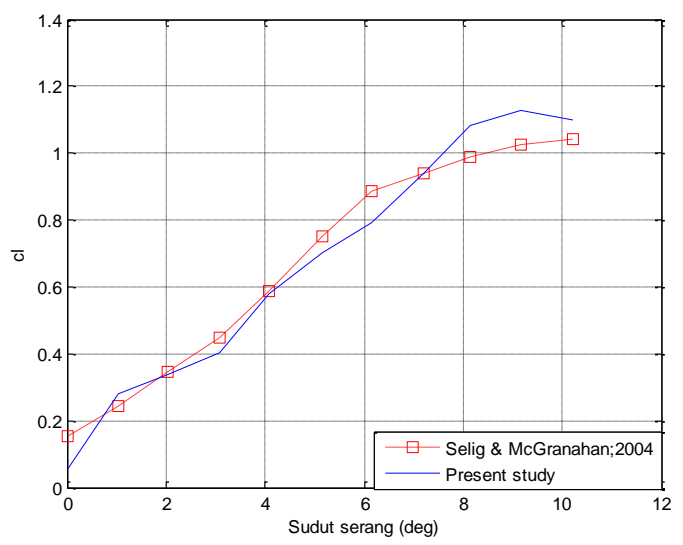

(a)

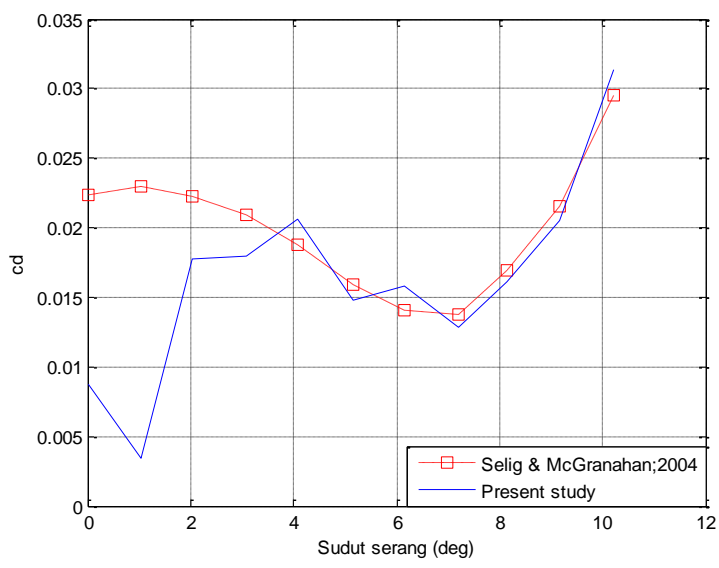

(b)

Gambar 12. 10 Koefisien gaya angkat dan (b) koefisien gaya hambat airfoil S822 untuk $R e=200000$

Untuk airfoil S822 hasil yang diperoleh ditunjukkan pada Gambar 11 dan 12. Gambar 11 menunjukkan distribusi kecepatan untuk kondisi tak viskos beserta harga $C_{l}$ untuk berbagai $\alpha$. Sedangkan koefisien gaya angkat dan koefisien gaya hambat terhadap perubahan sudut serang untuk kondisi viskos dengan $R e=200000$ masing-masing ditunjukkan pada Gambar 12a dan 12b. Dari Gambar 12a tampak bahwa sekalipun koefisien gaya angkat yang diperoleh dari analisis menggunakan metoda yang dikembangkan mempunyai kecende- rungan yang sama dengan hasil pengujian terowongan angin tetapi kesalahan yang terjadi cukup besar yaitu sekitar $11 \%$. Sedangkan pada Gambar $12 \mathrm{~b}$ dapat dilihat bahwa kesalahan yang terjadi pada koefisien gaya hambat antara hasil analisis dan hasil uji terowongan angin sekitar $21 \%$.

Berdasarkan uraian di atas tampak bahwa metoda yang dikembangkan memberikan harga koefisien gaya angkat yang cukup teliti. Meskipun demikian ketelitian tersebut cenderung menurun dengan bertambahnya ketebalan. Hal ini terjadi karena dalam analisis lapisan batas dimodelkan bahwa aliran yang terjadi dianggap melalui pelat datar. Oleh karena itu dapat dipahami bahwa semakin bertambahnya ketebalan airfoil maka ketelitian hasil analisis akan semakin menurun. Hal tersebut juga menyebabkan ketidakakuratan dalam penentuan koefisien gaya hambat. Di samping itu, hal lain yang perlu dicermati yang mempengaruhi secara signifikan akurasi dalam penentuan koefisien gaya hambat adalah analisis pada kondisi aliran memisah dimana di daerah ini diperlukan beberapa pengaturan (adjustment).

\section{Kesimpulan}

Berdasarkan hasil yang diperoleh dari analisis yang dilakukan terhadap airfoil E387, FX 63-137 dan S822 dapat disimpulkan bahwa kombinasi metode panel dengan interaksi viskos - tak viskos dengan pendekatan quasi - stedi mampu memberikan harga koefiisen gaya angkat dan sudut serang $\alpha$ stall serta koefisien gaya angkat maksimum yang cukup akurat. Tampak pula bahwa tingkat akurasi dalam peramalan koefisien gaya angkat semakin menurun seiring dengan bertambahnya ketebalan airfoil. Dari hasil yang diperoleh juga dapat disimpulkan bahwa metoda yang dikembangkan pada penelitian ini kurang memberikan akurasi yang baik dalam menentukan koefisien gaya hambat.

\section{Referensi}

[1] Sayma, A., Computational Fluid Dynamics, Abdulnaser Syma \& Ventus Publisihing ApS., Downloaded from www.bookboon.com (2009). 
[2] Drela, M. \& Youngren, H., 2001, XFOIL 6.9 User Primer. Cambridge, MA: Department of Aeronautics and Astronautics. Massachusettes Institute of Technology.

[3] Veldman, A. E. P., "New, Quasi-Simultaneous Method to Calculate Interacting Boundary Layers," AIAA Journal, Vol. 19, No. 1, pp. 79-85, 1981.

[4] Veldman, A. E. P., "Quasi - Simultaneous Viscous - Inviscid Interaction for Transonic Airfoil Flow," AIAA 2005-4801, June 2005.

[5] Veldman, A. E. P., “A Simple Interaction Law for Viscous-Inviscid Interaction,” J. Eng. Math, Vol 65, pp.367-383, 2009.

[6] Katz, J., Plotkin, A., Low-speed aerodynamics, $2^{\text {nd }}$ ed., Cambridge University Press (2001).

[7] Lighthill, M.J., “On displacement thickness,” Journal of Fluid Mechanics, Vol. 4, No. 4, pp. 383-392, 1958.

[8] Peter Sturdza, Yoshifumi Suzuki, Hervé Martins-rivas, David L. Rodriguez; A Quasi-Simultaneous Interactive Boundary - Layer Model for a Cartesian Euler Solver; 50th AIAA Aerospace Sciences Meeting including the New Horizons Forum and Aerospace Exposition, 09 - 12 January 2012, Nashville, Tennessee.

[9] Selig, M.S., Guglielmo, J.J., Broeren, A.P., Giguere, P., Summary of Low-Speed Airfoil Data, Volume 1, SoarTech Publication (1995).

\section{Apendiks}

Untuk relasi klosur laminar digunakan difinisi berikut

$$
\operatorname{Re}_{\theta} \equiv \frac{u_{e} \theta}{v} ; H^{*} \equiv \frac{\delta^{k}}{\theta} ; C_{f} \equiv \frac{\bar{C}_{f}}{\operatorname{Re}_{\theta}} ; C_{D}=\frac{\bar{C}_{D} H^{*}}{\operatorname{Re}_{\theta}}
$$

Sedangkan energy kinetic tebal perpindahannya

$$
\delta^{k}=H^{*} \theta=H^{*}(H) \frac{\delta^{*}}{H}
$$

Adapun relasi energi kinetik untuk factor bentuk, koefisien gesekan skin dan koefisien difusi masing-masing diberikan oleh relasi berikut

$H^{*}= \begin{cases}1.528+0.0111 \frac{(H-4.35)^{2}}{H+1}-0.0278 \frac{(H-4.35)^{3}}{H+1}-0.0002[(H-4.35) H]^{2} ; & H \leq 4.35 \\ 1.528+0.015 \frac{(H-4.35)^{2}}{H+1} ; & H>4.35\end{cases}$

$\bar{C}_{f}= \begin{cases}0.5\left[-0.07+0.0727 \frac{(5.5-H)^{3}}{H+1}\right] & H \leq 5.5 \\ 0.5\left[-0.07+0.0727\left(1-\frac{1}{H-4.5}\right)^{2}\right] & H>5.5\end{cases}$

$\bar{C}_{D}= \begin{cases}0.207+0.00205(4-H)^{5.5} & H \leq 4 \\ 0.207-0.0016 \frac{(H-4)^{2}}{1+0.02(H-4)^{2}} & H>4\end{cases}$

Untuk aliran turbulen berlaku

$$
H_{1}=\left\{\begin{array}{cc}
\frac{(0.5 H+1) H}{H-1} & H<2.732 \\
\frac{(0.5 h t+1) h t}{h t-1} & H \geq 2.723, \quad h t \leq 4 \\
1.75+\frac{5.2273 h t}{h t+5.818181} & H \geq 2.723, \quad h t>4
\end{array}\right.
$$


dimana $h t=0.5(H-2.732)+2.732$

Dengan koefisien gesekan kulit dinyatakan dengan

$C_{f s}=C_{f 0}\left(\frac{0.9}{H / H_{0}-0.4}-0.5\right)$

Dengan

$C_{f 0}=\frac{0.01013}{\log \operatorname{Re}_{\theta}-1.02}-0.00075$

dan

$H_{0}=\frac{1}{1-6.55 \sqrt{C_{f 0} / 2}}$

Adapun koefisien entrainmen diberikan oleh persamaan

$C_{E}=0.0306\left(H_{1}-3\right)^{-0.6169}$ 